\title{
Javanese Long Pepper's Extract as Alternative Energy on Sport for Gymnastics in Central Java
}

\author{
Tubagus Herlambang ${ }^{1}$, Galih Dwi Pradipta ${ }^{2}$ \\ ${ }^{1}$ Physical Education, Graduate School, Universitas Negeri Semarang, Indonesia \\ ${ }^{2}$ Universitas PGRI Semarang, Indonesia \\ ${ }^{1}$ Coresponding email: tubagusherlambang@yahoo.com
}

\begin{abstract}
Javanese long pepper knows for its stimulant effects for nerves to increase body stamina. The part that used as an aphrodisiac is its fruit, and it is suspected that the active compound which acts as an aphrodisiac is piperine. Javanese long pepper's extract has potential as an energy stimulant for sport. This study aims to find out the side effects of Javanese long pepper's consumption in energy production when doing sport. The subjects are 10 healthy male gymnasts of Central Java, they are between 18-21 years old. Increased energy of subject when using treadmill measure by analysing body stamina test, blood glucose test, blood pressure test. To observe the effect of consumption of chili pepper extract on energy production in the body on sports, the analysis of variance (ANOVA) was conducted and followed by least significant difference (LSD) which have $1 \%$ to $5 \%$ error possibility and DMRT (Duncan Multiple Range Test) which have $1 \%$ to 5\% error possibility. It is found that the consumption of Javanese long pepper's extract affects the energy productivity when doing sport.
\end{abstract}

Keywords: Javanese LongPepper, Stimulant, Energy, Sport

\section{Introduction}

Exercise is a very useful activity in maintaining a healthy body. Most sports involve both physical work and thinking ability. To optimize both physical work and thinking ability, we need energy or calorie from foods. Nutrients which serves as the main energy source is carbohydrate. Foods that contain carbohydrate, particularly complex carbohydrate, do not produce energy in a short time. Moreover, within a certain period, the energy from carbohydrates will decrease. Its a must to have good and durable stamina in sport. It takes a food processing technology to meet the needs of people who want to get energy more quickly and durable, especially when doing sports.

Basically, the combination of carbohydrates and vitamin B complex can produce energy with less rapid synthesis. To produce instant energy, it requires a stimulant or stimulus to produce energy. Type of stimulant that mostly uses in the food industry is the caffeine-type alkaloid. Caffeine found in agriculture commodity like tea, coffee, and tobacco. According to Nurachman (2004), stimulant works by blocking adenosine receptor. As we know when adenosine tied to the receptor, it could lower the nerve activity. This happens when we sleep. The resemblance structure of caffeine molecule and adenosine allow caffeine to bind with the receptor without decreasing the nerve activity. The consequence of nerve that works continually is extrication of hormone epinephrine. If this condition continues, it causes some effects, such as a higher heart rate, increased blood pressure, increased blood flow to the muscle, blood flow to the skin and internal organs decreases, and the release of glucose by the liver increases.

Javanese long pepper is one of the plants that known to have stimulant effect for nerve so it can increase human stamina. The hormonal effect from this plant called aphrodisiac. The chemical compound which acts as the aphrodisiac is steroid derivatives, saponins, alkaloid, tannin, and other compounds which increase blood flow. The part that used as an aphrodisiac is its fruit, and it is suspected that the active compound which acts as the aphrodisiac is piperine. Ochiai A, Miyata S, Shimizu M, Inoue J, Sato R. 2015. Piperine Induces Hepatic Low-Density Lipoprotein Receptor Expression through Proteolytic Activation of Sterol Regulatory Element-Binding Proteins. Piperine is a pungent constituent of black pepper (Piper nigrum) and long pepper (Piper longum) and is classified as an alkaloid. As a pharmacological agent, piperine has demonstrated anti-cancer, anti-inflammatory, and anti-microbial activities. In addition, several reports indicate that oral administration or dietary piperine improves high-fat dietinduced metabolic 
abnormalities, such as dyslipidemia, hepatic steatosis, and insulin resistance.

Bojjireddy N, Sinha RK, Subrahmanyam G. Piperine inhibits type II phosphatidylinositol 4-kinases: a key component in phosphoinositides turnover. Piperine is a pungent constituent of black pepper (Piper nigrum) and long pepper (Piper longum) and is classified as an alkaloid. As a pharmacological agent, piperine has demonstrated anti-cancer, anti-inflammatory, and anti-microbial activities. In addition, several reports indicate that oral administration or dietary piperine improves high-fat dietinduced metabolic abnormalities, such as dyslipidemia, hepatic steatosis, and insulin resistance. Piperine is an important bioenhancer and can increase the bioavailability of substances including curcumin, beta-carotene, amino acids, selenium and certain antibacterial compounds. Piperine has also been reported to have a wide range of applications because of its antimycobacterial, antihyperlipidemic, antiandrogenic, immunoregulatory and antitumor properties.

Caffeine and piperine have similarity it is a stimulus to produce energy. This allows the food industry to use the extract of Javanese long pepper, besides caffeine, that highpiperine content. Thus far, the potential of Javanese Long Pepper's extract as an energy stimulant in sports which need excessive and durable energy than other activities is unknown. Therefore, research on Javanese Long Pepper's Extract as Alternative Energy on Sport for Gymnasts in Central Java was conduct.

What is the impact of consuming an extract of Javanese Long Pepper to energy production when doing sport? To find out the impact of Javanese long pepper's consumption in energy production when doing sport.

\section{Methods}

By consume an extract of Javanese Long Pepper, we use a completely randomized design (CRD) with 1 factor as the experiment design. A sample of the extract is given to two groups which every group consisted of ten men, and receive treatments in the table below:
Table 1. Combination Treatments

\begin{tabular}{|c|c|l|}
\hline Days & Groups & \multicolumn{1}{|c|}{ Treatments } \\
\hline \multirow{2}{*}{1} & 1 & Consuming mineral water (control) \\
\cline { 2 - 3 } & 2 & $\begin{array}{l}\text { Consuming Extract of Javanene Long } \\
\text { pepper }\end{array}$ \\
\hline \multirow{2}{*}{2} & 1 & $\begin{array}{l}\text { Consuming Extract of Javanene Long } \\
\text { pepper }\end{array}$ \\
\cline { 2 - 3 } & 2 & Consuming mineral water (control) \\
\hline
\end{tabular}

\subsection{Research Implementation}

1. Make a Javanese long pepper's extract

Cut Javanese long peppers to small pieces then extract using water solvent.

2. Testing the extract of Javanese Long Pepper

a. Submaximal Physical activity test

b. Blood glucose test

c. Blood Pressure test

\subsection{Observation}

Observe subject in the groups before and after consuming the extract of Javanese Long Pepper when doing sports. Analyse the body stamina test, blood glucose test, blood pressure test.

\subsection{Time and Place of Research}

The research was conducted in July 2017 in one of a fitness centre in Semarang.

\subsection{Subject of Research}

The subject of research is ten male athletes of Persani Central Java from Grobogan and Pati regency, they are between 18-21 years old.

\section{Results and Discussion}

Subject Characteristics

Subjects who participate in this research are ten male athletes of Persani Central Java. They are 18-21 years old, have a healthytrained body, able to follow the physical training, and not consuming alcohol and drugs.

Statistical analysis shows std. deviation of test group 2.79285 was smaller than control group 2.88097. These data indicate that athletes who drink extracts of Javanese Long Pepper have extra energy when doing sport.

Javanese Long Pepper is one of the plants that known for having stimulus effect for nerve cells thus it can increase body stamina. The hormonal effect of this plant called an aphrodisiac. Based on scientific research, 
Javanese long pepper use as an aphrodisiac because it has an androgenic effect, as anabolic, and antivirus. In a literature review, it said that generally chemical compounds which work as an aphrodisiac are derivatives of steroid, saponins, alkaloid, tannin, and other compounds which increase blood circulation. Part of the plant that can use as the aphrodisiac is the fruit and it is suspected that the active compound which acts as the aphrodisiac is piperine (Nuraini, 2003)

Javanese long pepper (Piper retrofractum Vahl) is edible, has the androgenic effect, increasing testosterone on an experimental mouse, and its characteristics as simplisia (natural ingredients used for drugs and have not undergone any process changes generally the material has dried) and ethanol extract $95 \%$ has been known. Javanese long pepper seems has a good prospect to develop as Androgenic Phytopharmaca through various clinical research. Androgenic Phytopharmaca is a medicine that both safety and merit has proved, its substances consist of simplisia or galenic formation which have met the applicable requirements. (Kintoko, 2006).

Javanese long pepper contains piperine compound belongs to alkaloid class that usually used as a medicine. Piperine compound (C17H19NO3) is non-optically active base, formed from yellow crystalline, slightly soluble in water, soluble in alcohol, benzene, ether. When it tasted initially, it has no taste, after a while, it tasted strong, when piperine hydrolyzed, it will decompose into piperidin and piperic acid. Piperine is the main compound and nutritious substances contained in chillies of Java (Piperis retrofracti fructus) and use as reducing fever, reducing pain, antioxidants, reducing inflammation, having activity in gastric, antitumor, and immunomodulatory diseases (Istiqomah, 2013)

The caffeine-containing in javanese long pepper known as 1, 3, 7-trimethylxantin is a bitter alkaloid compound found in tea, coffee, and cocoa beans. The pharmacological effects of caffeine are as stimulants of the central nervous system, heart, and respiration. Another effect of caffeine is to relax the smooth muscles, stimulate the heart muscle, stimulate diuresis (excessive urine flow), and is used to handle dizziness. Caffeine performance has been investigated, but it is not clear how it contributes to pharmacological effects. Some of these are important as inhibitors of circular nucleotide phosphodiesterase, adenosine receptor antagonists, and modulation of calcium handling in cells (Nurachman, 2004).

Caffeine is medically known as trimethylxanthine, and a chemical formula $\mathrm{C} 8 \mathrm{H} 10 \mathrm{~N} 4 \mathrm{O} 2$. When isolated in its pure form, caffeine is a very bitter white crystalline powder. Medically caffeine is used as a cardiac stimulant and is also used to increase urine production. In addition, caffeine is also used to generate additional energy and is used in order to stay out of sleep longer. Many people feel that they cannot work in the morning without a cup of coffee to get caffeine and provide extra energy for them (Nugroho, 2008).

Caffeine is an opiate. Caffeine operates by using the same mechanisms as amphetamine, cocaine, and heroin that are used to stimulate the brain. The effect of caffeine is milder compared to amphetamine, cocaine, and heroin but caffeine can manipulate the same channels as those three drugs. In addition, caffeine can be addictive in consuming (Nugroho, 2008).

Alkaloids are compounds derived from amino acids and divided based on the amino acid skeletons that compose them. Alkaloids are not always produced from amino acids but sometimes by the import of ammonia or transamination compounds into the framework of a compound. Alkaloids are thought to be amino acid derivatives indicated by the presence of nitrogen atoms within the framework of a compound. Due to the nitrogen atoms we know are electron donors (excess of 1 pair of electrons) resulting in alkaline or alkali. So these class of compounds are called alkaloids (Saifudin, 2006).

Alkaloids have the ability to combine with $\mathrm{C} 2, \mathrm{C} 5$, and $\mathrm{C} 6$ groups so that it will produce various compounds with pharmacoforik groups (groups that interact with medicine receptors). These new clusters will result in various pharmacological activities. The moderate base characteristic of alkaloids makes the alkaloids are able to penetrate the biological barrier so that it is possible to reach the maximum receptor. Variation of nitrogen positions provide a certain $\mathrm{pH}$ range that facilitates isolation. From the aspect of pharmaceutical technology the water-soluble compound facilitates its formulation to be made dosage form and more guaranteed homogeneity (Saifudin, 2006). 
From the description above, proves that the content of Javanese long pepper extract that have been consumed in Central Java gymnastics athletes can increase stamina, it is proven from treatment at athletes of Central Java gymnastics who have consumed chili java extract, proved on normality data in the control group and treatment of normal data proved with data 0,200 , control group height 0,200 , treatment group 0,161 , weight control group 0,200, treatment group also equal 0,200, while blood glucose control group and treatment 0,200 . All data is normal because it shows results greater than 0.05 . Therefore if the data are normal the next test using independent T-Tests.

Table 2. Independent T-Test Data

\begin{tabular}{|c|c|c|c|c|c|}
\hline \multicolumn{6}{|c|}{ Group Statistics } \\
\hline & Grove & $\mathrm{N}$ & Mean & Sut Devistan & Ste Erro Masan \\
\hline \multirow[t]{2}{*}{$\mathrm{Kag}$} & Control & 5 & 15,4000 & 2.0007 & 120041 \\
\hline & Treatinert & $s$ & 40,4000 & 279285 & 124500 \\
\hline
\end{tabular}

The result of statistical analysis by using t-test find that the std deviation of treatment group showed smaller than the control group that is $2.79285<2.88097$. From these data shows that athletes who take the extract of chili extract of Javanese long pepper influence additional energy in sports activities.

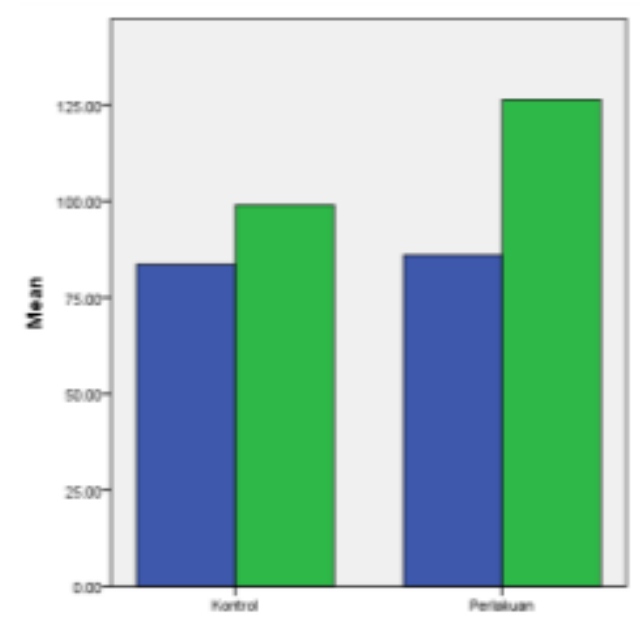

Figure 1. Histogram of physical strength score between control group and treatment group.

From 10 samples divided into 2 groups, among others, control group and treatment group, there is a significant difference between the two groups. These results can be seen from the results of independent T-Tests that show the results of 0.000 , it means the result is less than 0.005. While data of blood glucose level between control group and treatment, mean control group 15.4000 mean treatment group 40.4000 , std. deviation of control group 2.88097 and treatment group 2.79285.

\section{Conclusion}

Javanese long pepper contains piperine compounds, caffeine, and alkaloids that can provide energy stimulants in physical activity. It is proven that athletes who drink Javanese long pepper extracts have more energy than athletes who do not drink Javanese long pepper extracts in sports activities, after a physical exercise test with treadmill exercise.

\section{References}

Bojjireddy N, Sinha RK, Subrahmanyam G. Piperine inhibits type II phosphatidylinositol 4-kinases: a key component in phosphoinositides turnover. Molecular and cellular biochemistry. 2014 Aug 1;393(1-2):915.

Chithra S, Jasim B, Anisha C, Mathew J, Radhakrishnan EK. LC-MS/MS based identification of piperine production by endophytic Mycosphaerella sp. PF13 from Piper nigrum. Applied biochemistry and biotechnology. 2014 May 1;173(1):30-5.

Diwan V, Poudyal H, Brown L. 2011. Piperine Attenuates Cardiovascular, Liver and Metabolic Changes in High Carbohydrate, High Fat-Fed Rats. Cell Biochem Biophys (2013) 67:297-304.

Istiqomah. 2013. Perbandingan metode ekstraksi maserasi dan sokletasi terhadap kadar piperin buah cabe jawa (Piperis retrofracti fructus). Skripsi. UIN Syarif Hidayatullah. Jakarta

Kintoko. 2006. Prospek pengembangan tanaman obat. Prosiding Persidangan Antara Bangsa Pembangunan Aceh, Universitas Kebangsaan Malaysia, Bangi :178-188.

Moeloek, N. 2010. Uji Klinik Ekstrak Cabe Jawa (Piper Retrofractum Vahl) Sebagai Fitofarmaka Androgenik Pada Pria Hipogonad. Majalah Kedokteran Indonesia Vo.60 No.6 
Nurachman, Zeily. 2004. Minuman Energi. www.kompas.com

Nuraini A. 2003. Mengenal etnobotani beberapa tanaman yang berkhasiat sebagai aprodisiaka. Info POM, Badan Pengawas Obat dan Makanan Republik Indonesia IV(10):1-4.

Ochiai A, Miyata S, Shimizu M, Inoue J, Sato R. Piperine Induces Hepatic LowDensity Lipoprotein Receptor Expression through Proteolytic Activation of Sterol Regulatory ElementBinding Proteins. PloS one. 2015 Oct 2;10(10):e0139799.
Pentak D. In vitro spectroscopic study of piperine-encapsulated nanosize liposomes. European Biophysics Journal. 2016 Mar 1;45(2):175-86.

Saifudin, Azis. 2006. Alkaloid: Golongan Paling Prospek Menghasilkan Obat Baru. Farmasi Universitas M uhammadiyah. Surakarta

Soumyanath A, Venkatasamy R, Joshi M, Faas L, Adejuyigbe B, Drake AF, Hider RC, Young AR. UV irradiation affects melanocyte stimulatory activity and protein binding of piperine. Photochemistry and photobiology. 2006 Nov;82(6):1541-8. 